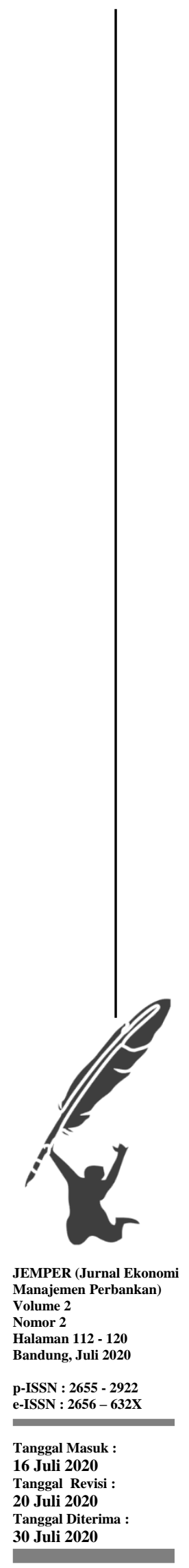

JEMPER(Jurnal Ekonomi Manajemen Perbankan)

http://jurnal.usbypkp.ac.id/index.php/jemper

\title{
PENGARUH INFLASI, SUKU BUNGA, NILAI TUKAR DAN PRODUK DOMESTIK BRUTO TERHADAP RETURN SAHAM SEKTOR PERTANIAN DAN SEKTOR PERTAMBANGAN PERIODE 2009 - 2019
}

\author{
Dyah Saputri 1 \\ Universitas Sangga Buana YPKP Bandung \\ dyahsptr19@gmail.com \\ Tahmat ${ }^{2}$ \\ Universitas Sangga Buana YPKP Bandung \\ tahmatdj@gmail.com \\ Erna Garnia ${ }^{3}$ \\ Universitas Sangga Buana YPKP Bandung \\ ernagarnia2@gmail.com \\ Deden Rizal ${ }^{4}$ \\ Universitas Sangga Buana YPKP Bandung \\ drizalthea@gmail.com
}

\begin{abstract}
This study aims to determine the effect of inflation, interest rates, exchange rates, and gross domestic product on stock returns in the agricultural and mining sectors companies listed on the Indonesia Stock Exchange (IDX) for the period 2009 - 2019 either partially or simultaneously. The sampling technique used in this study was purposive sampling, and there were 12 companies that were used at research objects. This research used the quantitative research method using panel data regression analysis method. The result showed that partially inflation and exchange rates have a significant negative effect on stock returns, while interest rates and gross domestic product have no effect on stock returns. Based on the results of the simultaneousl inflation, interest rates, exchange rates, and gross domestic product have a effect on stock returns.
\end{abstract}

Keywords : Inflation, Interest Rates, Exchange Rates, and Gross Domestic Product and Stock Return

\begin{abstract}
Abstrak
Penelitian ini bertujuan untuk mengetahui pengaruh inflasi, suku bunga, nilai tukar dan produk domestik bruto terhadap return saham sektor pertanian dan sektor pertambangan yang terdaftar di Bursa Efek Indonesia (BEI) periode 2009 - 2019 baik secara parsial maupun simultan. Teknik pengambilan sampel pada penelitian ini menggunakan purposive sampling, didapatkan 12 perusahaan yang dijadikan objek penelitian. Penelitian ini menggunakan metode penelitian kuantitatif dengan menggunakan metode analisis regresi data panel. Hasil penelitian menunjukkan bahwa secara pasial inflasi dan nilai tukar berpengaruh negatif terhadap return saham sedangkan suku bunga dan produk domestik bruto tidak berpengaruh terhadap return saham. Berdasarkan hasil penelitian secara simultan inflasi, suku bunga, nilai tukar dan produk domestik bruto berpegaruh terhadap return saham sektor pertanian dan sektor pertambangan periode $2009-2019$.
\end{abstract}

Katakunci : Inflasi, Suku Bunga, Nilai Tukar, Produk Domestik Bruto dan Return Saham 


\section{PENDAHULUAN}

Pasar modal dapat dikatakan sebagai sarana kegiatan berinvestasi bagi perusahaan atau pemerintah dalam hal pendanaan dengan cara menjual saham ataupun surat-surat berharga lainnya dengan memanfaatkan jasa perantara dalam kegiatannya. Penelitian ini menggunakan konsep Arbitrage Pricing Theory (APT) yang mana merupakan suatu model untuk menilai suatu aset keuangan. Dalam perkembangannya APT ini banyak sekali digunakan dengan berbagai variabel-variabel makro ekonomi sebagai penentu return saham. Memaksimalkan return saham merupakan salah satu prioritas para investor dalam berinvestasi. Return saham merupakan hasil keuntungan (capital gain) atau kerugian (capital loss) yang diperoleh dari hasil investasi atau trading saham yang dilakukan dalam kurun waktu tertentu. Maka dari itu ada istilah "high risk, high return" yang artinya jika suatu investasi semakin tinggi resikonya maka semakin tinggi pula return yang didapatkan oleh seorang investor nantinya.

Grafik dibawah menunjukkan perkembangan inflasi, nilai tukar, suku bunga, produk domestik bruto dan return saham sektor pertanian dan sektor pertambangan.

\section{Perkembangan Inflasi, Nilai Tukar, Suku Bunga, Produk Domestik Bruto dan Return Saham Sektor Pertanian dan Sektor Pertambangan}

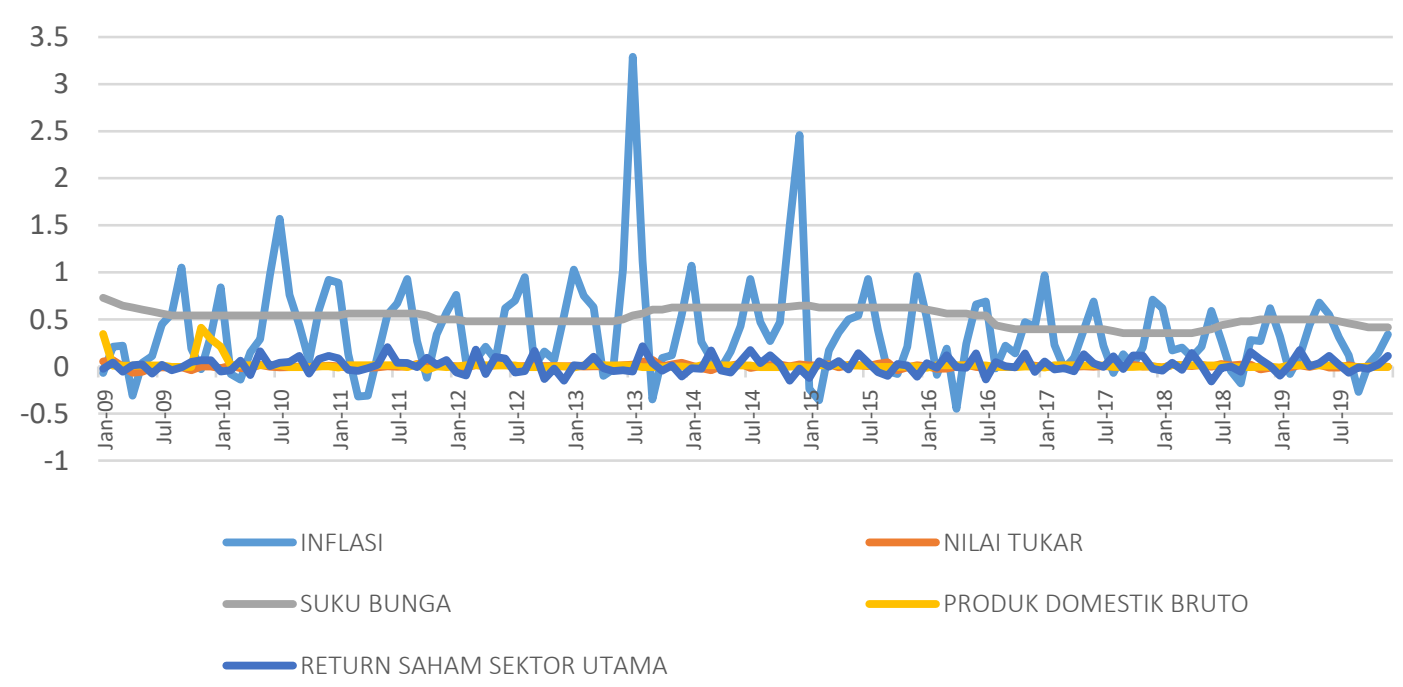

Grafik 1

Perkembangan inflasi, suku bunga, nilai tukar dan produk domestik bruto dan return saham sektor pertanian dan sektor pertambangan periode $2009-2019$.

Pada grafik 1 terlihat perkembangan inflasi, nilai tukar, suku bunga, produk domestik bruto dan return saham sektor pertanian dan sektor pertambangan periode Januari 2009 Desember 2019. Pada bulan Januari 2009 - September 2012 lalu November 2012 Desember 2014 dilanjut Januari 2015 - Februari 2018 dan April 2018 - Desember 2019 ketika inflasi naik return saham pun ikut naik begitu pula ketika inflasi turun return saham pun ikut turun. Pada grafik 1 return saham sektor pertanian dan sektor pertambangan periode Januari 2009 - Desember 2019 ada kecenderungan ketika suku bunga turun maka return saham juga ikut turun dan sebaliknya ketika suku bunga naik return saham juga ikut naik. Pada tahun 2009 - 2019 kecenderungan return saham mengalami penurunan berbanding terbalik dengan nilai tukar yang cenderung naik. Pada bulan Februari tahun 2011, 2016 dan 2017 produk domestik bruto naik sedangkan return sahamnya turun. 
Dyah Saputri ${ }^{1}$, Tahmat ${ }^{2}$, Erna Garnia ${ }^{3}$, Deden Rizal ${ }^{4}$, /Pengaruh Inflasi, Suku Bunga, Nilai Tukar dan Produk Domestik Bruto Terhadap Return Saham Sektor Pertanian dan Sektor Pertambangan Periode 2009 2019

Walaupun sektor pertanian dan pertambangan memiliki catatan peningkatan yang cukup baik, tetap saja para investor harus selalu memperhatikan perkembangan ekonomi baik itu di dalam negeri ataupun perkembangan ekonomi secara global.

Dalam perkembangannya banyak yang sudah meneliti tentang pengaruh variabelvariabel makro ekonomi terhadap return saham namun memiliki hasil yang berbeda-beda. Berdasarkan penelitian yang dilakukan oleh Bambang Sudarsono dan Bambang Sudiyatno (2016) menyatakan bahwa inflasi berpengaruh negatif signifikan terhadap return saham. Penelitian yang dilakukan oleh I Nyoman Sutrisna Adi Putra dan I.G.A.N. Budiasih (2016) menyatakan bahwa produk domestik bruto tidak berpengaruh terhadap return saham.

\section{LITERATUR}

\section{Return Saham}

Realized Return atau return realisasi dapat dikatakan sebagai return yang sudah terjadi, biasanya disebut sebagai retun saham historis karena nantinya akan dipakai sebagai salah satu alat ukur untuk mengukur kinerja suatu perusahaan. Expected return atau return ekspektasi adalah pengembalian yang belum terjadi, maksudnya harapan para investor terhadap pembembalian investasinya pada masa yang akan datang disebut return ekspektasi (Jogiyanto, 2015).

\section{Inflasi}

Inflasi merupakan suatu keadaan meningkatnya harga-harga pada umumnya atau suatu keadaan senantiasa turunnya nilai uang karena meningkatnya jumlah uang yang beredar tidak diimbangi dengan peningkatan persediaan barang (Setyaningrum dan Muljono, 2016).

\section{Suku Bunga}

Suku bunga adalah harga dari penggunaan dana investasi (loanable funds). Tingkat suku bunga merupakan salah satu indikator dalam menentukan apakah seseorang akan melakukan investasi atau menabung (Boediono, 2014).

Nilai Tukar

Nilai tukar adalah harga mata uang yang dimiliki oleh suatu negara dinilai oleh negara lainnya. Harga yang dimaksud adalah sejumlah uang yang harus dikeluarkan dan nilai mata uang tersebut bisa tetap atau berubah menjadi lebih mahal atau murah tergantung dari jumlah permintaan dan penawaran terhadap mata uang tersebut (Pujawati, dkk. 2015).

Produk Domestik Bruto

Produk domestik bruto adalah total pendapatan yang dihasilkan oleh warga negara itu sendiri maupun warga negara asing dari semua barang dan jasa di dalam suatu negara (Hasyim, 2016).

\section{Hipotesis}

"Ada pengaruh inflasi, suku bunga, nilai tukar dan produk domestik bruto baik secara parsial maupun simultan terhadap return saham sektor pertanian dan sektor pertambangan periode 2009 - 2019”.

\section{METODE PENELITIAN}

Penelitian ini menggunakan metode penelitian kuantitatif. Pada penelitian ini juga menggunakan metode penelitian deskriptif dan verifikatif. Sumber data yang didapatkan pada penelitian ini yaitu sumber sekunder karena data yang diambil tidak langsung dari perusahaan yang akan diteliti melainkan dari catatan-catatan angka historis dari data inflasi, suku bunga, nilai tukar dan produk domestik bruto yang dipublikasikan secara umum. Data inflasi, suku bunga bank Indonesia dan produk domestik bruto diperoleh dari situs resmi 
Dyah Saputri ${ }^{1}$, Tahmat ${ }^{2}$, Erna Garnia ${ }^{3}$, Deden Rizal ${ }^{4}$, /Pengaruh Inflasi, Suku Bunga, Nilai Tukar dan Produk Domestik Bruto Terhadap Return Saham Sektor Pertanian dan Sektor Pertambangan Periode 2009 2019

Badan Pusat Statistik yaitu www.bps.go.id sedangkan nilai tukar rupiah terhadap dollar AS diperoleh dari situs resmi Bank Indonesia yaitu www.bi.go.id dan return saham sektor pertanian dan sektor pertambangan diperoleh dari harga saham yang berasal situs resmi Bursa Efek Indonesia yaitu www.idx.co.id dan https://finance.yahoo.com. Cara untuk pengambil sampel pada penelitian ini yaitu dengan menggunakan purposive sampling, berdasarkan teknik pengambilan sampel tersebut didapatkan 12 perusahaan yang menjadi sampel pada penelitian ini.

Teknik analisis data yang digunakan pada penelitian ini yaitu analisis desktiptif digunakan untuk menganalisis data dengan cara mendeskripsikan atau menggambarkan data yang telah terkumpul dan analisis regresi data panel dengan melakukan estimasi model data panel yaitu Common Effect Model, Fixed Effect Model dan Random Effect Model yang selanjutnya menentukan metode estimasi data panel yaitu dengan Uji Chow, Uji Hausman, dan Uji Lagrange Multiplier. Selanjutnya melakukan Uji Asumsi Klasik dengan menggunakan Uji Normalitas, Uji Heteroskedstisitas, Uji Multikolienieritas, dan Uji Autokorelasi. Untuk melihat sumbangan pengaruh yang diberikan variabel independen (X) terhadap variabel dependen (Y) dilakukan Uji Koefisien Determinasi $\left(\mathrm{R}^{2}\right)$. Pengujian hipotesis dilakukan dengan menggunakan Uji t untuk melihat pengaruh dari masing-masing variabel independen $(\mathrm{X})$ terhadap variabel dependen $(\mathrm{Y})$ secara parsial dan Uji F dilakukan untuk mengetahui pengaruh variabel independen $(\mathrm{X})$ terhadap variabel dependen $(\mathrm{Y})$ secara bersama-sama atau simultan.

\section{HASIL DAN PEMBAHASAN}

\section{Analisis Deskriptif}

Inflasi dengan angka tertinggi terjadi pada Desember 2014 sedangkan inflasi dengan angka terendah terjadi pada September 2012. Suku bunga tertinggi terjadi pada Januari 2009 sedangkan suku bunga terendah terjadi pada tahun 2017 dan 2018. Nilai tukar rupiah terhadap dollar AS tertinggi terdapat pada bulan Oktober 2018 dan nilai tukar terendah terdapat pada Oktober 2010. Produk domestik bruto tertinggi terjadi pada triwulan IV tahun 2010 dan produk domestik bruto terendah terjadi pada triwulan II tahun 2009.

\section{Uji Statistik}

\section{Pemilihan Model Terbaik Data Panel}

Tabel 1 hasil uji lagrange multiplier dibawah menunjukkan nilai probabilitas Breusch-Pagan sebesar 0,2453>0,05 sehingga model yang paling tepat digunakan dalam penelitian ini yaitu Common Effect Model.

Tabel 1. Uji Lagrange Multiplier

\begin{tabular}{llll}
\hline & & Test Hypothesis & \\
& Cross-section & Time & Both \\
\hline Breusch-Pagan & 1.349898 & 1.185353 & 2.535251 \\
\hline & $(0.2453)$ & $(0.2763)$ & $(0.1113)$ \\
\hline
\end{tabular}

Sumber : Data diolah (2020) 


\section{Uji Asumsi Klasik}

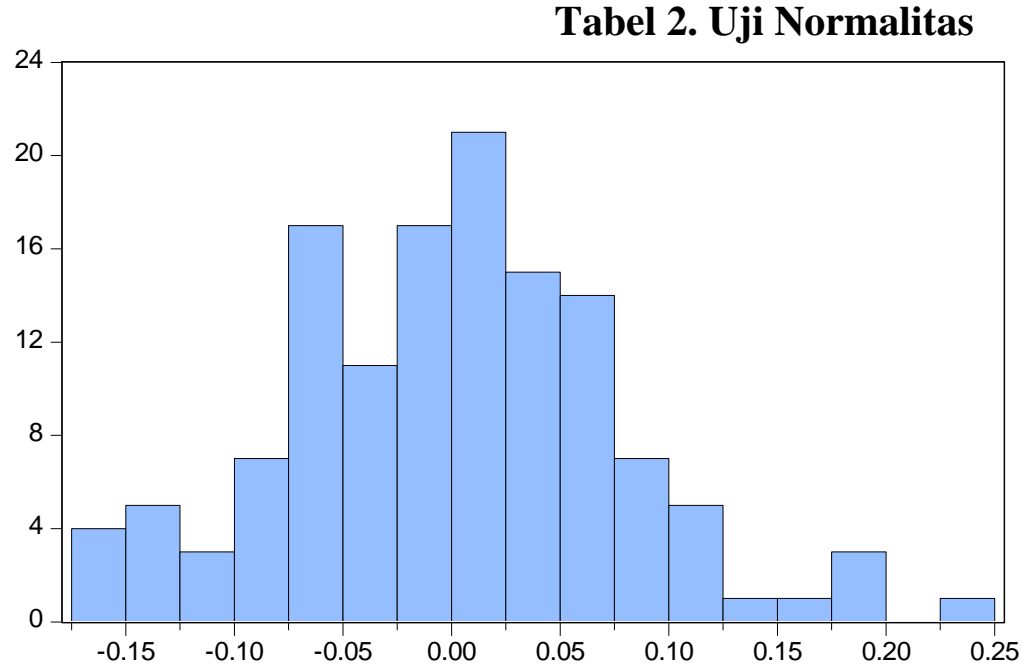

Series: Standardized Residuals

Sample 20092019

Observations 132

Mean $\quad 7.78 \mathrm{e}-18$

Median $\quad 0.003008$

Maximum $\quad 0.244577$

Minimum $\quad-0.160895$

Std. Dev. $\quad 0.076615$

Skewness $\quad 0.287134$

Kurtosis $\quad 3.438958$

Jarque-Bera 2.873568

Probability $\quad 0.237691$

Sumber : Data diolah (2020)

Tabel 2 uji normalitas diatas dapat terlihat bahwa nilai Probabilitas Jarque-Bera sebesar 2,873568>0,05 dengan nilai Probability sebesar 0,237691 > 0,05 maka dapat disimpulkan bahwa data penelitian berdistribusi dengan normal dan uji asumsi klasik normalitas sudah terpenuhi.

Tabel 3. Uji Heteroskedastisitas

\begin{tabular}{lllll}
\multicolumn{1}{c}{ Variable } & \multicolumn{1}{c}{ Coefficient } & Std. Error & t-Statistic & Prob. \\
\hline C & 0.019780 & 0.026198 & 0.755002 & 0.4516 \\
\hline Inflasi & 0.003972 & 0.008733 & 0.454776 & 0.6500 \\
\hline Suku Bunga & 0.074092 & 0.050069 & 1.479800 & 0.1414 \\
\hline Nilai Tukar & -0.035351 & 0.226914 & -0.155790 & 0.8764 \\
\hline PDB & -0.106397 & 0.078369 & -1.357653 & 0.1770 \\
\hline
\end{tabular}

Sumber : Data diolah (2020)

Tabel 3 uji heteroskedastisitas diatas menunjukkan bahwa nilai probabilitas inflasi sebesar 0,6500, suku bunga sebesar 0,1414, nilai tukar sebesar 0,8764, dan produk domestik bruto sebesar 0,1770 yang mana itu semua lebih besar dari 0,05. Artinya, dalam model regresi ini tidak terjadi heteroskedastisitas.

Tabel 4. Uji Multikolinearitas

\begin{tabular}{lcccc} 
& Inflasi & Suku Bunga & Nilai Tukar & PDB \\
\hline Inflasi & 1.000000 & 0.078841 & 0.096238 & -0.071864 \\
\hline Suku Bunga & 0.078841 & 1.000000 & 0.080755 & 0.148581 \\
\hline Nilai Tukar & 0.096238 & 0.080755 & 1.000000 & 0.054433 \\
\hline PDB & -0.071864 & 0.148581 & 0.054433 & 1.000000 \\
\hline
\end{tabular}

Sumber : Data diolah (2020)

Tabel 4 hasil uji multikolinearitas tampilan matriks pair-wise correlation antar variabel independen diatas menghasilkan nilai $<0,8$ maka dapat diartikan bahwa pada model regresi ini tidak terdapat multikolinearitas. 
Dyah Saputri $^{1}$, Tahmat ${ }^{2}$, Erna Garnia ${ }^{3}$, Deden Rizal ${ }^{4}$, /Pengaruh Inflasi, Suku Bunga, Nilai Tukar dan Produk Domestik Bruto Terhadap Return Saham Sektor Pertanian dan Sektor Pertambangan Periode 2009 2019

Tabel 5. Uji Autokorelasi

\begin{tabular}{lllc}
\hline F-statistic & 4.145735 & Durbin-Watson stat & 1.667428 \\
\hline Prob(F-statistic) & 0.003438 & & \\
\hline Subs
\end{tabular}

Sumber : Data diolah (2020)

Tabel 5 hasil uji autokorelasi diatas diperoleh nilai Durbin-Watson hitung sebesar 1,667428. Karena $\mathrm{N}=12$ dan $\mathrm{K}=4$ maka diperoleh nilai $\mathrm{dl}=0,5120$ dan nilai $\mathrm{du}=2,1766$. Sehingga $\mathrm{dl}<\mathrm{dw}<\mathrm{du}$, maka dapat disimpulkan bahwa pada model regresi ini tidak terdapat autokorelasi.

\section{Koefisien Determinasi $\left(\mathbf{R}^{2}\right)$}

Tabel 6 hasil regresi dibawah menunjukkan nilai R-squared sebesar 0,115494 atau $11,54 \%$. Maka koefisien determinasi menunjukkan bahwa pengaruh yang diberikan inflasi, suku bunga, nilai tukar dan produk domestik bruto yaitu sebesar $11,54 \%$ sedangkan sisanya yaitu sebesar $88,46 \%$ dipengaruhi oleh variabel yang tidak diteliti pada penelitian ini.

Tabel 6. Koefisien Determinasi $\left(\mathbf{R}^{2}\right)$

\begin{tabular}{lc}
\hline R-squared & 0.115494 \\
\hline Adjusted R-squared & 0.087635 \\
\hline
\end{tabular}

Sumber : Data diolah (2020)

Pengujian Hipotesis

Pengujian Hipotesis Parsial (Uji t)

Tabel 7. Hasil Uji t

\begin{tabular}{|c|c|c|c|c|}
\hline Variable & Coefficient & Std. Error & t-Statistic & Prob. \\
\hline $\mathrm{C}$ & -0.011613 & 0.041303 & -0.281166 & 0.7790 \\
\hline Inflasi & -0.028375 & 0.013768 & -2.060896 & 0.0414 \\
\hline Suku Bunga & 0.072988 & 0.078935 & 0.924649 & 0.3569 \\
\hline Nilai Tukar & -1.168397 & 0.357737 & -3.266080 & 0.0014 \\
\hline PDB & -0.015319 & 0.123550 & -0.123990 & 0.9015 \\
\hline
\end{tabular}

Sumber : Data diolah (2020)

Hasil uji t diatas menunjukkan inflasi dan nilai tukar berpengaruh terhadap return saham, karena nilai Prob. > 0,05.

\section{Hasil Pengujian Simultan (Uji F)}

Tabel 8. Hasil Uji F

\begin{tabular}{llll}
\hline F-statistic & 4.145735 & Durbin-Watson stat & 1.667428 \\
\hline Prob(F-statistic) & 0.003438 & & \\
\hline Sumber : Data diolah (2020) & & &
\end{tabular}

Hasil uji f diatas menunjukkan nilai F-statistic yaitu sebesar 4,145735 > dari f tabel sebesar 4,12 dan nilai Prob(F-statistic) sebesar 0,003438 < nilai $\alpha$ sebesar 0,05. Maka dapat disimpulkan bahwa variabel independen $(\mathrm{x})$ berpengaruh secara simultan atau bersama-sama terhadap variabel dependen (y). 
Dyah Saputri ${ }^{1}$, Tahmat ${ }^{2}$, Erna Garnia ${ }^{3}$, Deden Rizal ${ }^{4}$, /Pengaruh Inflasi, Suku Bunga, Nilai Tukar dan Produk Domestik Bruto Terhadap Return Saham Sektor Pertanian dan Sektor Pertambangan Periode 2009 2019

\section{HASIL PEMBAHASAN PENELITIAN}

Perhitungan uji hipotesis secara parsial didapatkan nilai thitung inflasi yaitu sebesar -2,060896 lebih kecil dari t tabel sebesar 2,36462 dengan tingkat signifikansi sebesar 0,0414 dimana lebih kecil dari nilai $\alpha$ sebesar 0,05 , maka dapat disimpulkan inflasi berpengaruh negatif signifikan terhadap return saham sektor pertanian dan sektor perbankan periode 2009 - 2019. Hal ini dapat terjadi karena pada saat inflasi harga barang-barang akan mengalami kenaikan secara terus menerus mengakibatkan meningkatnya biaya yang akan dikeluarkan oleh suatu perusahaan sehingga profitabilitas perusahaan akan menurun dan laba yang diperoleh juga akan ikut menurun, juga berdampak pada kurang tertariknya para investor untuk berinvestasi mengakibatkan harga saham turun dan berdampak pada penurunan return saham.

Perhitungan uji hipotesis secara parsial didapatkan nilai t hitung suku bunga yaitu sebesar 0,924649 lebih kecil dari t tabel sebesar 2,36462 dengan tingkat signifikansi sebesar 0,34569 dimana lebih besar dari nilai $\alpha$ sebesar 0,05 , maka dapat disimpulkan suku bunga tidak berpengaruh terhadap return saham sektor pertanian dan sektor perbankan periode 2009 - 2019. Hal ini sejalan dengan penelitian yang dilakukan oleh Suriyani dan Sudiartha (2018) dimana suku bunga yang tinggi dapat menyebabkan harga bahan baku menjadi mahal namun perusahaan akan memilih untuk menggunakan pembiayaan lain yang lebih murah dan efisien sehingga tidak akan mempengaruhi profitabilitas perusahaan terhadap return saham yang akan diterima oleh investor.

Perhitungan uji hipotesis secara parsial didapatkan nilai t hitung nilai tukar yaitu sebesar -3,266080 lebih kecil dari t tabel sebesar 2,36462 dengan tingkat signifikansi sebesar 0,0014 dimana lebih besar dari nilai $\alpha$ sebesar 0,05 , maka dapat disimpulkan nilai tukar berpengaruh negatif signifikan terhadap return saham sektor pertanian dan sektor perbankan periode 2009 - 2019. Pergerakan nilai tukar rupiah terhadap dollar AS juga sangat penting bagi perusahaan sektor pertanian dan sektor pertambangan yang melakukan ekspor dan impor dalam kegiatannya. Melemahnya nilai tukar dapat menyebabkan biaya produksi yang dikeluaran perusahaan naik. Biaya produksi yang tinggi juga dapat mengurangi laba perusahaan sehingga kinerja perusahaan menurun sehingga mempengaruhi harga saham dan return saham.

Perhitungan uji hipotesis secara parsial didapatkan nilai t hitung produk domestik bruto yaitu sebesar -0,123990 lebih kecil dari t tabel sebesar 2,36462 dengan tingkat signifikansi sebesar 0,9015 dimana lebih besar dari nilai $\alpha$ sebesar 0,05 , maka dapat disimpulkan produk domestik bruto tidak berpengaruh terhadap return saham sektor pertanian dan sektor perbankan periode 2009 - 2019. Hal ini sejalan dengan penelitian yang dilakukan oleh I Nyoman Sutrisna Adi Putra dan I.G.A.N. Budiasih (2016) bahwa produk domestik tidak berpengaruh terhadap return saham. Produk domestik bruto menandakan bagaimana kesejahteraan suatu negara. Semakin meningkatnya konsumsi masyarakat terhadap barang dan jasa maka akan semakin meningkat pula tingkat kesejahteraan masyarakat namun produk domestik bruto belum tentu meningkatkan pendapatan perkapita karena perkembangan investasi di bidang rill tidak dibarengi dengan perkembangan investasi di bidang pasar modal.

Berdasarkan hasil uji hipotesis secara simultan didapatkkan nilai F-statistic yaitu sebesar 4,145735 lebih besar dari f tabel sebesar 4,12 dan nilai Prob(F-statistic) sebesar 0,003438 kurang dari nilai $\alpha$ sebesar 0,05 sehingga dapat dikatakan bahwa inflasi, suku bunga, nilai tukar dan produk domestik bruto berpengaruh secara simultan atau bersamasama terhadap return saham. Maka dapat disimpulkan hipotesis $\mathrm{H}_{1}$ diterima artinya ada pengaruh antara inflasi, suku bunga, nilai tukar dan produk domestik bruto terhadap return saham sektor pertanian dan sektor pertambangan periode 2009 - 2019. 
Dyah Saputri ${ }^{1}$, Tahmat ${ }^{2}$, Erna Garnia ${ }^{3}$, Deden Rizal ${ }^{4}$, /Pengaruh Inflasi, Suku Bunga, Nilai Tukar dan Produk Domestik Bruto Terhadap Return Saham Sektor Pertanian dan Sektor Pertambangan Periode 2009 2019

\section{SIMPULAN}

Variabel inflasi, suku bunga, nilai tukar dan produk domestik bruto memberikan pengaruh terhadap return saham sebesar $11,54 \%$ sedangkan sisanya sebesar $88,46 \%$ dipengaruhi oleh variabel lain. Berdasarkan hasil penelitian uji t, secara parsial inflasi dan nilai tukar berpengaruh kearah negatif terhadap return saham sektor pertanian dan sektor pertambangan periode 2009 - 2019. Secara parsial suku bunga dan produk domestik bruto tidak berpengaruh terhadap return saham sektor pertanian dan sektor pertambangan periode 2009 - 2019. Berdasarkan hasil uji f, inflasi, suku bunga, nilai tukar dan produk domestik bruto secara simultan berpengaruh terhadap return saham sektor pertanian dan sektor pertambangan periode $2009-2019$.

\section{DAFTAR PUSTAKA}

\section{Buku dan Skripsi}

Andiari, F. (2017). Pengaruh Stock Split Terhadap Pergerakan Harga Saham di Pasar Saham Syariah Indonesia. Bandar Lampung: UIN Raden Intan Lampung.

Azis, M., Minarti, S., \& Nadir, M. (2015). Manajemen Investasi Fundamental, Teknikal, Perilaku Investor dan Return Saham. Yogyakarta: Deepublish.

Fahmi, I. (2012). Pengantar Pasar Modal. Bandung: Alfabeta.

Fitriana, Tahmat, \& Firdaus, A. (2019). Aksi Korporasi dan Pengaruhnya Terhadap Perdagangan Saham di Bursa Efek Indonesia (BEI). Bandung: Lekkas.

Hadi, N. (2013). Pasar Modal (Acuan Teoritis dan Praktis Investasi di Instrumen Pasar Modal). Yogyakarta: Graha Ilmu.

Merinda Putri. (2018). Pengaruh Faktor Ekonomi Makro Terhadap Return Saham Pada Saham-Saham Industri Non Keuangan Yang Terdaftar Di Bursa Efek Indonesia Tahun 2014-2016. Abstrak Skripsi Sarjana Universitas Lampung, Bandar Lampung.

Nasarudin, M. I., Surya, I., \& Yustiavandan, I. (2014). Aspek Hukum Pasar Modal Indonesia. Jakarta: Kencana.

Sugiyono. (2017). Metode Penelitian Kuantitatif, Kualitatid dan R\&D. Bandung: Alfabeta.

\section{Sumber Jurnal}

Gusni, \& Riantani, S. (2017). Penggunaan Arbitrage Pricing Theory Untuk Menganalisis Return Saham Syariah. Ultima Management : Jurnal Ilmu Manajemen.

Hasyim, L. T. (2016). Peran Perbankan Syariah Terhadap Pertumbuhan Ekonomi Sektor Rill di Indonesia. AKRUAL (Jurnal Akutansi), 9.

Pujawati, P. E., Wiksuana, I. B., \& Artini, L. S. (2015). Pengaruh Nilai Tukar Rupiah Terhadap Return Saham Dengan Profitabilitas Sebagai Variabel Intervening. EJurnal Ekonomi dan Bisnis Universitas Udayana, 226.

Putra, I. S., \& Budiasih, I. (2016). Pengaruh Produk Domestik Bruto Negara Indonesia, Ukuran Perusahaan Dan Dividen Payout Ratio Pada Return Saham. E-Jurnal Akuntansi.

Sudarsono, B., \& Sudiyatno, B. (2016). Faktor-Faktor yang Mempengaruhi Return Saham Pada Perusahaan Property dan Real Estate yang Terdaftar Pada Bursa Efek Indonesia Tahun 2009 s/d 2014. Jurnal Bisnis dan Ekonomi (JBE).

Sunariyah. (2013). Pengantar Pengetahuan Pasar Mdal. Malang: STIE Malang.

Suriyani, N. K., \& Sudiartha, G. M. (2018). Pengaruh Tingkat Suku Bunga, Inflasi dan Nilai Tukar Terhadap Return Saham di Bursa Efek Indonesia. E-Jurnal Manajemen Unud, 3176.

Sutawijaya, A., \& Zulfahmi. (2012). Penngaruh Faktor-Faktor Ekonomi Terhadap Inflasi Indonesia. Jurnal Organisasi dan Manajemen, 87-90.

Vireyto, N., \& Sulasmiyati, S. (2017). Analisis Pengaruh Return On Asset, Return On Equity dan Earning Per Share Terhadap Harga Saham (Studi Pada Perusahaan Bank BUMN 
Dyah Saputri ${ }^{1}$, Tahmat ${ }^{2}$, Erna Garnia ${ }^{3}$, Deden Rizal ${ }^{4}$, /Pengaruh Inflasi, Suku Bunga, Nilai Tukar dan Produk Domestik Bruto Terhadap Return Saham Sektor Pertanian dan Sektor Pertambangan Periode 2009 2019

yang Listed di Bursa Efek Indonesia Periode 2006-2016. Jurnal Administrasi Bisnis, 77.

\section{Sumber Internet}

www.bps.go.id

www.bi.go.id

https://finance.yahoo.com

https://www.idx.co.id 